\title{
Institutional Sources of Resilience in Global ICT Leaders - Harness the Vigor of Emerging Power
}

\author{
Chihiro Watanabe \\ National University of Singapore, Singapore \& University of Jyvaskyla, Finland \\ Kashif Naveed \\ University of Jyvaskyla, Finland \\ Weilin Zhao \\ Fujitsu Research Institute, Japan
}

\begin{abstract}
In light of the significant impacts on global economy both nations and firms witnessed a dramatic advancement of information and communication technology (ICT). There was particularly bi-polarization between ICT advanced and growing economies compelling a vicious cycle between ICT advancement and its productivity decline in these economies. The institutional sources of resilience were analyzed. On the basis of an empirical analysis comparing technopreneurial performance in world top 500 ICT firms by market value, sales and profit over the last decade, resilient firms maintaining world top 100 position by all three values over the whole period were identified. Institutional sources enabling resilient firms maintain leading position can largely be attributed to co-evolutionary acclimatization ability, which harnesses the vigor of emerging power of counterparts both in home countries and in advanced countries as well as growing economies in a co-evolutional way. Such ability maximizes synergy between efficiency and resilience in their technopreneurial management. Contrasting business model in global ICT firms with and without resilience structure suggests the sources of emerging trap due to ICT advancement and endorsed the significance of co-evolutionary acclimatization. This suggests the significance of institutional coevolution between ICT advanced and growing economies that enables both economies to harness the vigor of partners for global sustainability.
\end{abstract}

Keywords: Resilience, Institutional Source, ICT Leaders, Co-evolutionary Acclimatisation, Emerging Power.

\section{INTRODUCTION}

Journal of Technology

Management for Growing Economies

Vol. 5 No. 1

April 2014

pp. 7-34

and Honda, majority of its electric machinery firms (which are global ICT firms) such as Panasonic, Sony and Sharp suffered significant deficits. Similar bi-polarization can be observed in the global competitive race between ICT advanced economies and ICT growing economies. Contrary to a conspicuous economic growth in the latter, the former suffers from greater

\section{CHITKARA 兯 UNIVERSITY}

(C)2014 by Chitkara University. All Rights Reserved. 
Watanabe, C. Naveed, K. Zhao, W. stagnation (Cowen, 2011) except Singapore (Zhao et al., 2013, Watanabe, 2013).

Such a bi-polarization and subsequent "sudden death" can be attributed to misunderstanding the new stream beyond anticipation and unable to adapt to new environment as a consequence of clinging to efficiency oriented traditional business model. While looking at the current global socioeconomy, we can clearly observe that it is in the midst of a stage beyond anticipation due to such events viz., the US sub-prime mortgage crisis, the Lehman shock, a Euro currency crisis, Japan's March 11 disaster, flooding in Thailand, Hurricane Sandy's and powerful typhoon's damage to New York and Philippines. Digitalization of manufacturing processes, a third industrial revolution initiated by the maker movement and also dramatic advancement of the Internet represent another stream of beyond anticipation that has shaken up the business model of firms. Trends in aging and a declining birthrate may also lead to a beyond anticipation world once they exceed a certain threshold.

In order to correspond to such new stream, optimal balance between efficiency and resilience in the whole perspective of innovation value chain encompassing emergence, diffusion and utilization would be essential.

To date, only a few studies have pointed the significance of resilience for sustainability. Resilience generally means ability to recover from some shock or disturbance and this concept is popular particularly in ecology, physics, network and psychology. In materials, for example, resilience can be defined as the ability of a material to absorb energy when its elasticity is deformed, and release that energy upon unloading (Campbell, 2008). Grimm and Wissel (1997) postulated (i) stability, (ii) constancy, (iii) persistence, (iv) resistance, (v) elasticity, and (vi) domain of attraction as necessary requirements to resilience. These concepts have been applying broadly in economic and business as well as industrial and organizational safety and exploring new perspectives in assessing the performance of technoprenerial strategy of global ICT firms. Watanabe et al. (2003) postulated a concept of resilience as a source of survival strategy for high-technology firms. Focusing on this dimension they realized resilience is the ability of an ecosystem to continue functioning despite occasional and severe disturbance as Marten (2001) defined, and more generally, the capacity of a sustained body to recover from, or adjust smoothly to external changes, shocks or crises. Primentel et al. (2000) stressed that resilience plays a significant role in maintaining ecological integrity. Ulanowicz (1995) identifies the role of resilience, in terms of this integrity, as a core function of a system consisting of vigor,

Journal of Technology Management for Growing Economies, Volume 5, Number 1, April 2014 
organization and resilience. Based on this resilience role as a core function for maintaining system integrity, Watanabe et al. (2003) postulated that it is essential for high-technology firms to set a resilient structure, thereby maintaining an operating income to sales while minimizing elasticity of factors with uncertainty. This concept could be supportive in envisioning a sustainable strategy for high-technology firms in global competition. Neely and Hii (1998) posited that the innovation capacity of a firm regards three important and interrelated perspectives viz., (i) culture, (ii) internal processes, and (iii) external environment. Ilmola and Casti (2013) defined resilience as a concept consisting of three elements viz., (i) adaptability (the capability to absorb an extreme event or shock), (ii) agility (the capacity to benefit from the new situation which the shock generates, and (iii) assimilation (the capacity for using a shock as a trigger for renewal and improvement). This concept prompts us the significance of transforming crises or shocks into a springboard for new innovation as demonstrated by Japan against the energy crises in the 1970s, Finland against disruption of the USSR in the beginning of the 1990s and Korea against Asian financial crisis in 1997 (Watanabe, 2009a).

Notwithstanding the foregoing postulates, none has ever taken in-depth analysis of the institutional sources of resilience, which should be the basis of business model for global competition in the midst of beyond anticipation.

Prompted by the foregoing observation, this paper analyzes the forefront of the new stream in global Information and Communication Technology (ICT) competition race. Empirical analyses focusing on the ICT driven developing trajectory in 100 nations and also 500 global ICT firms are undertaken. Based on the comparative analysis between resilient and noresilient trajectories, suggestions for resilient business model are extracted.

The paper reviews transnational pan-global bi-polarization phenomena in nations as well as global ICT firms. The study analyzes consequence of the bi-polarization both in nations and global ICT firms. Technopreneurial structure between resilient and non-resilient firms are compared. Structural source of the trap of ICT advancement is analyzed in the subsequent section. The study demonstrates lessons from resilient model both by country and firm. Section 6 briefly summarizes noteworthy findings, policy implications supportive to resilient business and also the points for future works.

\section{Trans National Pan-global Bi-polarization}

Dramatic advancement of ICT has led ICT driven logistic growth in both nations and global ICT firms as demonstrated in Figs. $1^{1}$ and 2 (Zhao et al., 2013).

Journal of Technology Management for Growing Economies, Volume 5, Number 1, April 2014
Institutional

Sources of

Resilience 
Watanabe, C.

Naveed, K.

Zhao, W.

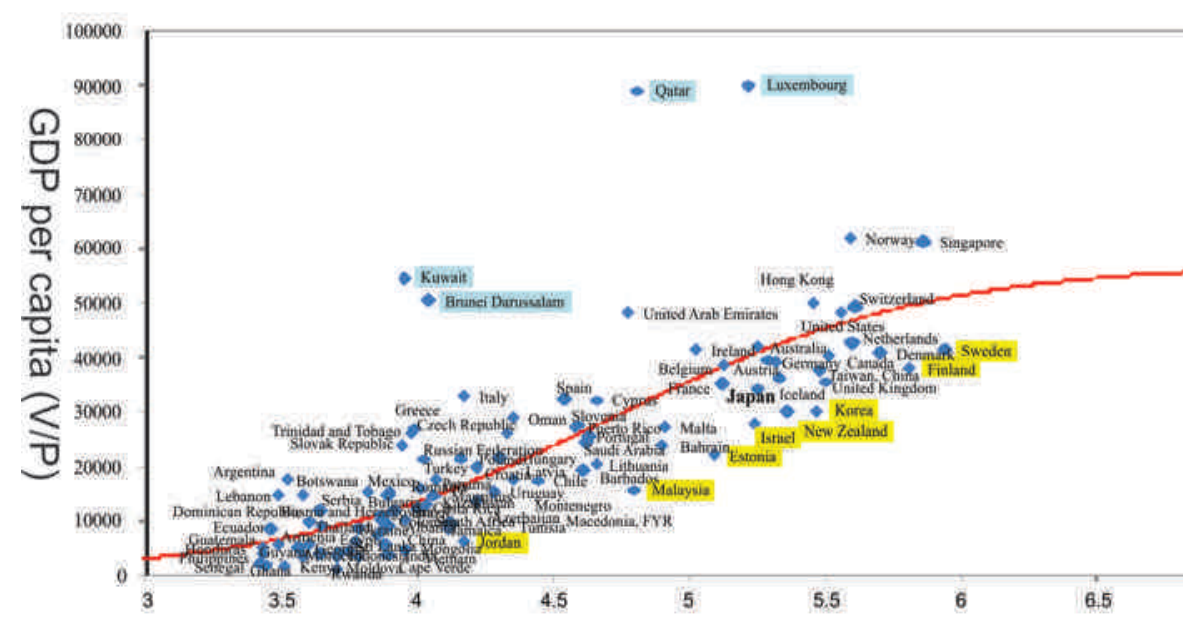

IT by Networked Readiness Index ( NRI )

Figure1: ICT Driven Economic Development Trajectory in 100 Countries (2011)

Sources: The Global Information Technology Report 2012 (World Economic Forum, 2012), World Economic Outlook Database (IMF, 2012).

$$
\begin{aligned}
& \text { V/P; GDP per capita, } N \text {; carrying capacity, NRE: Networked readiness index, } \\
& D_{l}, D_{z} \text { dummy variables, and } a, b, c, d \text { : coefficients. } \\
& \frac{V}{P}=\frac{N}{1+e^{-2 N 2 R+h t}}+c D_{1}+d D_{2} \\
& \begin{array}{|c|c|c|c|c|c|}
\hline \boldsymbol{N} & \boldsymbol{a} & \boldsymbol{b} & \boldsymbol{c} & \boldsymbol{d} & \\
\hline 57239 & 1.68 & -7.90 & 46434 & 12913 & \text { w/ k0.985 } \\
\hline(9.62) & (7.58) & (-9.80) & (14.54) & (-5.25) & \\
\hline
\end{array}
\end{aligned}
$$

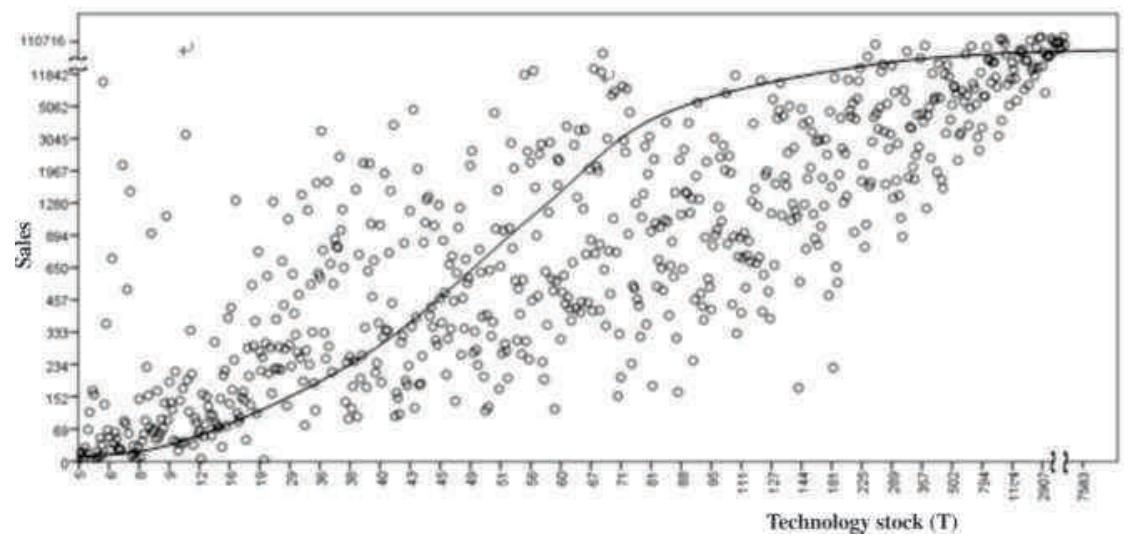

Figure 2 : ICT Driven Development Trajectory in 500 Global ICT Firms (2010) Source: Economics of Industrial Research and Innovation (EU, 2011). 


$$
\mathrm{S}=\frac{\mathrm{N}}{1+b e^{-a f}}+c D
$$

S: sales, N: carrying capacity, T: technology stoc D: dummy variables, and a, b, c: coefficients.
Institutional

Sources of

Resilience

\begin{tabular}{|c|c|c|c|c|}
\hline$N$ & $a$ & $b$ & $c$ & \\
\hline 42668 & 0.002 & 22.61 & 45184 & \multirow{2}{*}{ adj. $R^{2} 0.885$} \\
\cline { 1 - 4 }$(28.31)$ & $(26.02)$ & $(10.23)$ & $(30.32)$ & \\
\hline
\end{tabular}

Such a logistic growth inevitably results in bi-polarization ${ }^{2}$ among nations as well as global ICT firms as demonstrated in Figs. 3 and 4 where $\mathrm{x}$ and $\mathrm{y}$ signify ICT (or R\&D) and marginal productivity of technology increase toward the origin of the coordinate axes (Watanabe, 2013, Zhao et al., 2013) .

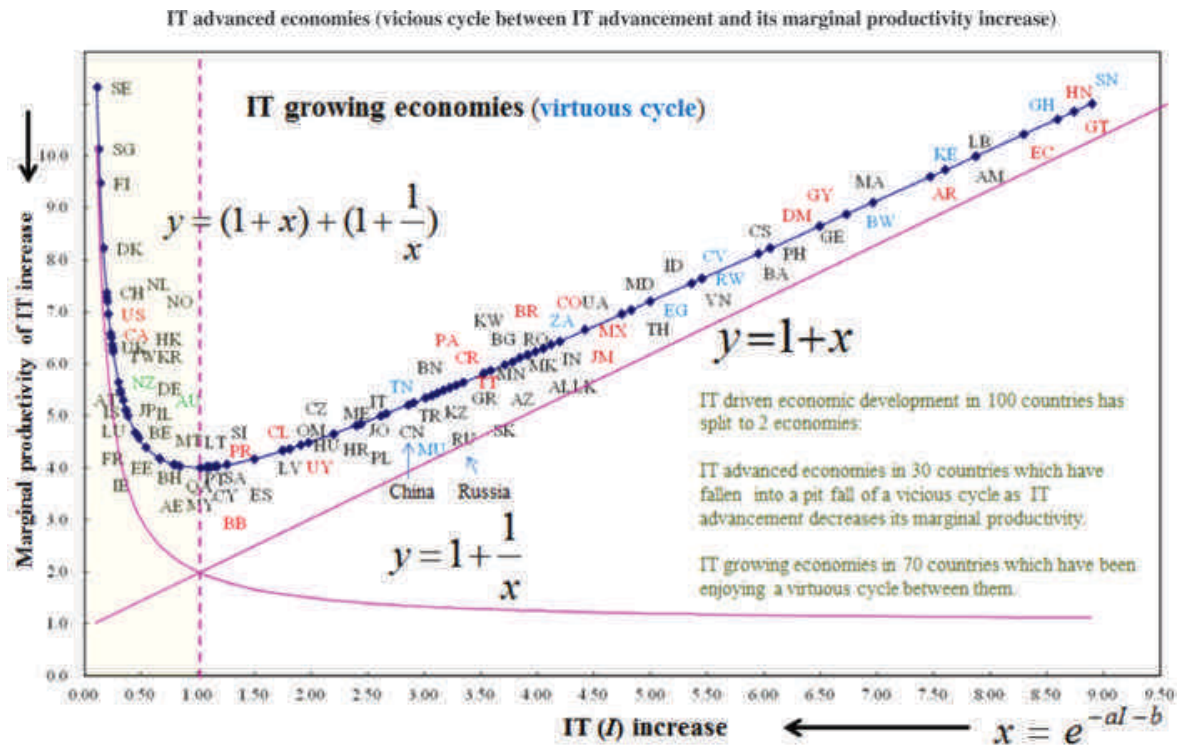

Figure 3: Bi-polarization of ICT Driven Economic Development Trajectory in 100 Nations (2011)

Sources: The Global Information Technology Report 2012 (World Economic Forum, 2012), World Economic Outlook Database (IMF, 2012).

Consequently, 100 nations have split to two economies as demonstrated in Table 1. While ICT growing 70 nations (nations with NRI ranking 31 to 100 in Table 1) have been enjoying a virtuous cycle between ICT advancement and its marginal productivity increase as generally anticipated, ICT advanced 30 nations (NRI ranking 1 to 30 ) have fallen into a pit of a vicious cycle as IT advancement decreases its marginal productivity against anticipation. 
Watanabe, C. Naveed, K. Zhao, W.
Table 1: Bi-polarization of Development Trajectories by Networked Readiness Index in 100 Nations (2011) - 1-30: ICT advanced economies (vicious cycle)

\begin{tabular}{|c|c|c|c|}
\hline I SE Sweden 5.94 & 26. MT Mata 4.91 & 51 CN China 4.11 & $76 \mathrm{MX}$ Mexico 3.82 \\
\hline 2 SG Singapore 5.86 & 27 BH Bahrain 4.90 & 52 TR Turkey 4.07 & 77 TH Thailand 3.78 \\
\hline $3 \mathrm{FI}$ Finland 5.81 & 28 QA Qatar 4.81 & 53 MU Mauritius 4.06 & $78 \mathrm{MD}$ Moldova 3.78 \\
\hline 4 DK Denmark 5.70 & 29 MY Malaysia 4.80 & 54 BN Brunei Darussalam 4.04 & 79 EG Egypt 3.77 \\
\hline $5 \mathrm{CH}$ Switzerlind 5.61 & $30 \mathrm{AE}$ Unitou Atub Ëminnes 4.77 & $55 \mathrm{KZ}$ Kazakhstan 4.03 & 80 ID Indonesia 3.75 \\
\hline 6 NE Netherlands 5.60 & 31 LT Lithuania 4.66 & 56 RU Russian Federation 4.02 & 81 CV Cape Verde 3.71 \\
\hline 7 NO Norway 5,59 & 32 CY Cyprus 4.66 & 57 PA Panama 4.01 & 82 RW Rwanda 3.70 \\
\hline 8 US United States 5,56 & 33 PT Portugal 4.63 & 58 CR Costa Rica 4,00 & 83 VN Vietnam 3,70 \\
\hline 9 CA Canata 5.51 & 34 SA Saudi Arabia 4.62 & 59 GR Greece 3.99 & 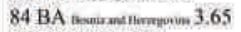 \\
\hline 10 UK United Kingdom S.S0 & 35 BB Barbados 4.61 & 60 TT Trinidad and Tobago 3.98 & 85 CS Serbia 3.64 \\
\hline 11 TW Tawan, Chinu 5.48 & 36 PR Puerto Rico 4.59 & 61 AZ Azerbsijan 3.95 & 86 PH Philippines 3.64 \\
\hline 12 KR Korea, Rep, 5.47 & 37 SI Slovenia 4.58 & $62 . \mathrm{KW}$ Kuwait 3.95 & 87 DM toveninican Hepublise 3.60 \\
\hline 13 HK Hong Kong SAR 5.46 & 38 ES Spain 4.54 & $63 \mathrm{MN}$ Mongolia 3.95 & 88 GE Georgia 3.60 \\
\hline 14 NZ New Zealand 5.36 & 39 CL Chile 4.44 & 64 SK Slovak Republic 3.94 & 89 BW Botswana 3.58 \\
\hline 15 is Iscland 5,33 & 40 OM Oman 4.35 & 65 BR Brazil 3.92 & 90 GY Guyana 3,58 \\
\hline $16 \mathrm{DE}$ Gertmany 5.32 & 41 LV Latvia 4,35 & 66 MK Macedonia, FYR 3.91 & 91 MA Morocco 3.56 \\
\hline 17 AU Australia 5.29 & $42 \mathrm{CZ}$ Crech Republic 4.33 & 67 RO Romania 3.90 & 92 AR Argentina 3.52 \\
\hline 18 JP Japan 5.25 & 43 HU Hungary 4.30 & $68 \mathrm{AL}$ Albania 3.89 & 93 KE Kenya 3,51 \\
\hline 19 AT Austria 5.25 & 44 UY Uruguay 4.28 & $69 \mathrm{NN}$ India 3.89 & 94 AM Amenia 3,49 \\
\hline 20 IL Isracl $5: 24$ & 45 HR Croatia 4.22 & 70 BG Bulgaria 3.89 & 95 LB Lebanon 3.49 \\
\hline 21 LU Luxembourg 5.22 & 46 ME Montenegro 4.22 & 71 LK Sri Lanka 3.88 & 96 EC Ecuador 3,46 \\
\hline 22 BE Belgium 5.13 & 47 JO Jordan 4.17 & 72 ZA South Africa 3,87 & 97 GH Ghana 3.44 \\
\hline 23 FR France 5.12 & 48 IT Italy 4.17 & 73 CO Colombia 3.87 & 98 GT Guatemala 3.43 \\
\hline 24 EE Estonia 5.09 & 49 PL Poland $4: 16$ & 74 JM Jamaica 3.86 & $99 \mathrm{HN}$ Hondurás 3.43 \\
\hline $25 \mathrm{EE}$ Ineland 5.02 & $50 \mathrm{TN}$ Tunisia 4.12 & 75 UA Ukraine 3.85 & 100 SN Senegal 3.42 \\
\hline
\end{tabular}

a Color of the country indicates: N: Eurasian, N: Oceania, N: America, N: Africa

Source: The Global Information Technology Report 2012 (World Economic Forum, 2012)

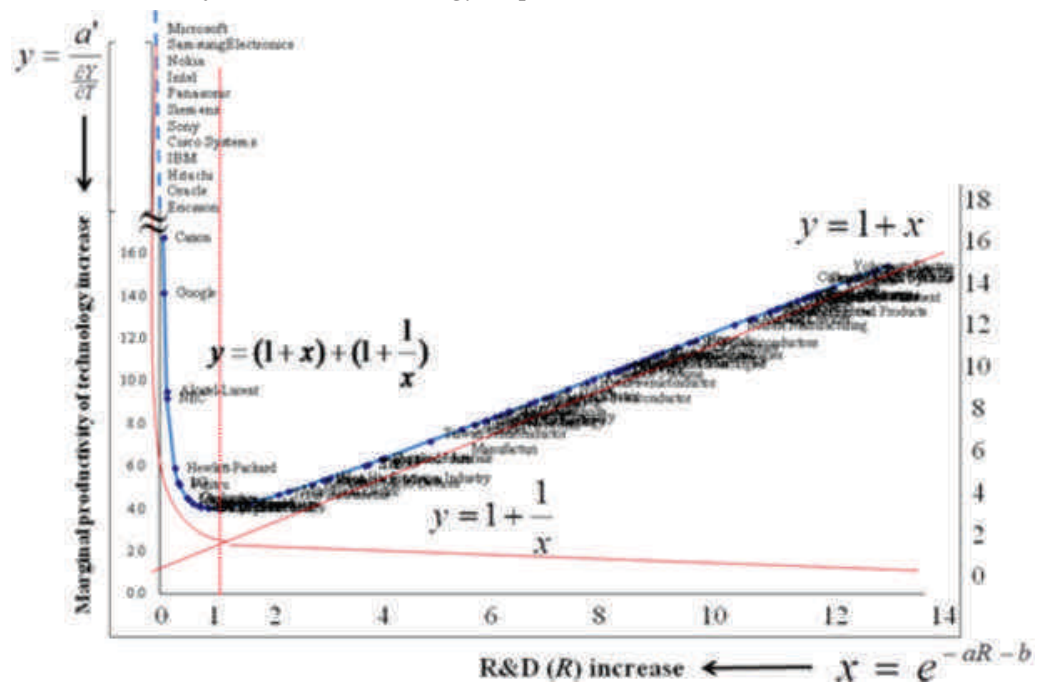

Figure 4: Bi-polarization of ICT Driven Development Trajectory in 500 Global ICT Firms (2010)

Source: Economics of Industrial Research and Innovation (EU, 2011).

Similarly, highly R\&D intensive firms among 500 global ICT firms (R\&D matured ICT firms: 19 in 2007 and 21 in 2010) have fallen in a pit of a vicious

Journal of Technology Management for Growing Economies, Volume 5, Number 1, April 2014 
cycle between R\&D investment centered by ICT and its marginal productivity as increase in former results in decline for the later. The remaining firms (R\&D increasing ICT firms) have been enjoying a virtuous cycle between them as $\mathrm{R} \& \mathrm{D}$ increase leads to productivity increase.

Table 2 demonstrates such a contrast. Top 19 and 21 global ICT firms with respect to R\&D investment in 2007 and 2010, respectively led by ICT giant such as Microsoft, Samsung and Nokia have fallen in a pit of a vicious cycle between their R\&D investment increase and marginal productivity of technology decline. Table 2: Bi-polarization in 500 Global ICT Firms in 2007 and 2010 (by R\&D level order)

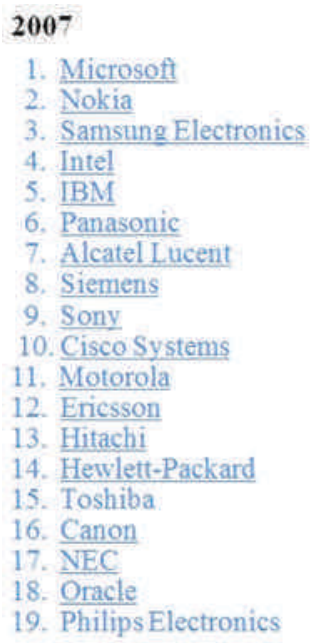

20. Fujitsu

21. Texas Instruments

22. SAP

23. Google

24. San Microsy stems

25. Advanced Micro Devices

26. Qualcomm

27. LG Electronics

28. EMC

29. Nortel Networks

30. Infineon Technologies

32. Sharp

48. Apple

Fims in blue indicate R\&D matured ICT fims (19 in 2007 and 21 in 2010) which suffer a vicious cycle between $R \& D$ and marginal productivity of technology while fims in black indicate R\&D increasing firms which enjoy a virtuous cycle between them. 2010

Undemined 17 fims indicates fims categorized in matured ICT fims in both 2007 and

Source: Industrial R\&D Investment Scoreboard (EU, annual issues).
2010

1. Microsoft

2. Samsung Electronics

3. Nokia

4. Intel

5. Panasonic

6. Siemens

8. Cisco Systems

9. IBM

10. Hitachi

11. Oracle

12. Ericsson

13. Canon

14. Google

15. Alcatel-Lucent

16. NEC

17. Hewlett-Packard

18. LG

19. Fujitsu

20. Qualcomm

21. Motorola

22. Huawei Technologies

23. SAP

24. EMC

25. Philips Electronics

26. STMicrolectronics

27. Fuji Film

28. Sharp

29. Apple

30. Broadcom
7. Sony
Institutional

Sources of

Resilience 
Watanabe, C. Naveed, K. Zhao, W.

\section{CONSEQUENCE OF THE BI-POLARIZATION}

\section{Great Stagnation in ICT Matured Economies}

While a dramatic advancement in ICT provides strong anticipation in significant economic growth in ICT advanced economies, contrary to such anticipation, their economic growth engine has disappeared except in Singapore which ranks second in the world by NRI in 2011. Fig. 5 traces trends in real GDP increase rate in countries among ICT advanced economies by comparing those in ICT growing economies such as BRIC over the last half century encompassing industrial society (1961-1990), information society (1991-2000) and after net bubble bursting (2001-2010).

Looking at the Fig. 5 we clearly note that contrary to conspicuous economic growth in ICT growing economies, GDP growth rates in countries among ICT advanced economies in this century, particularly during the latter half of the first decade of this century have demonstrated the great stagnation (Cowen, 2011) except Singapore.

Real GDPIncrease Rate in $2006-2010$ (\% p.a.)
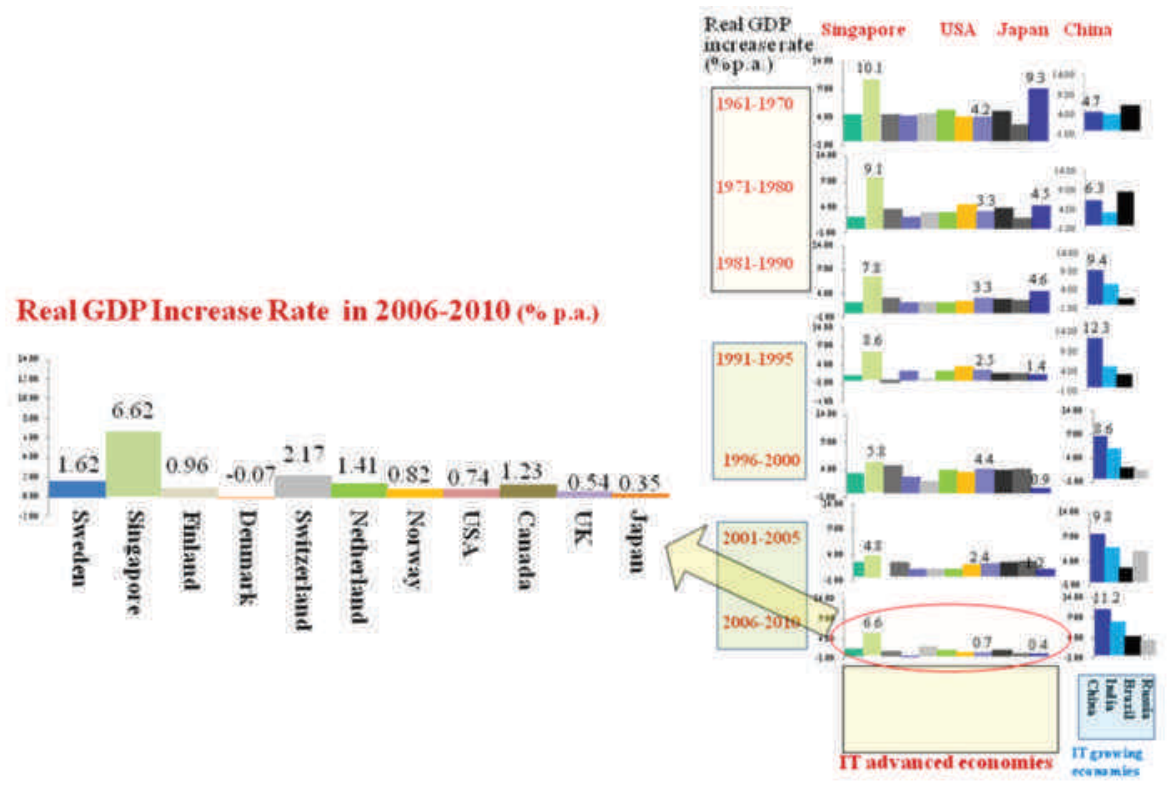

Figure 5: Stagnation in Economic Growth in ICT Advanced Economies

$$
\text { (2006-2010) }
$$

Source: World Economic Outlook Database (IMF, annual issues).

Such a contrast is not only present in the great stagnation in national level but also in the market competition in global ICT firms. Fig. 6 compares net income of Japan's leading high-technology firms in 2011, which demonstrates

Journal of Technology Management for Growing Economies, Volume 5, Number 1, April 2014 
a conspicuous bi-polarization between firms maintaining profits and those suffering serious deficits. Contrary to profits in automobile firms such as Nissan, Toyota and Honda, majority of electric machinery firms (they are global ICT firms) such as Panasonic, Sony and Sharp suffered significant deficits. Under such circumstances, only Canon maintained conspicuous profits. Hitachi's profits can be attributed to shifting to social infrastructure field not due to indigenous electric machinery innovation efforts.

Significant deficits in world leading electric machinery firms (global ICT firms) as Panasonic, Sony and Sharp can largely be attributed to overlooking new beyond anticipation streams such as (i) dramatic advancement of the Internet, (ii) digitalization of manufacturing, (iii) new stream of emerging economies, and (iv) subsequent growing anger of consumers (Watanabe, 2013).

This can be a consequence of clinging to traditional efficiency oriented business model without paying careful attention to resilience against new stream that led to foregoing bi-polarization (Watanabe, 2013).

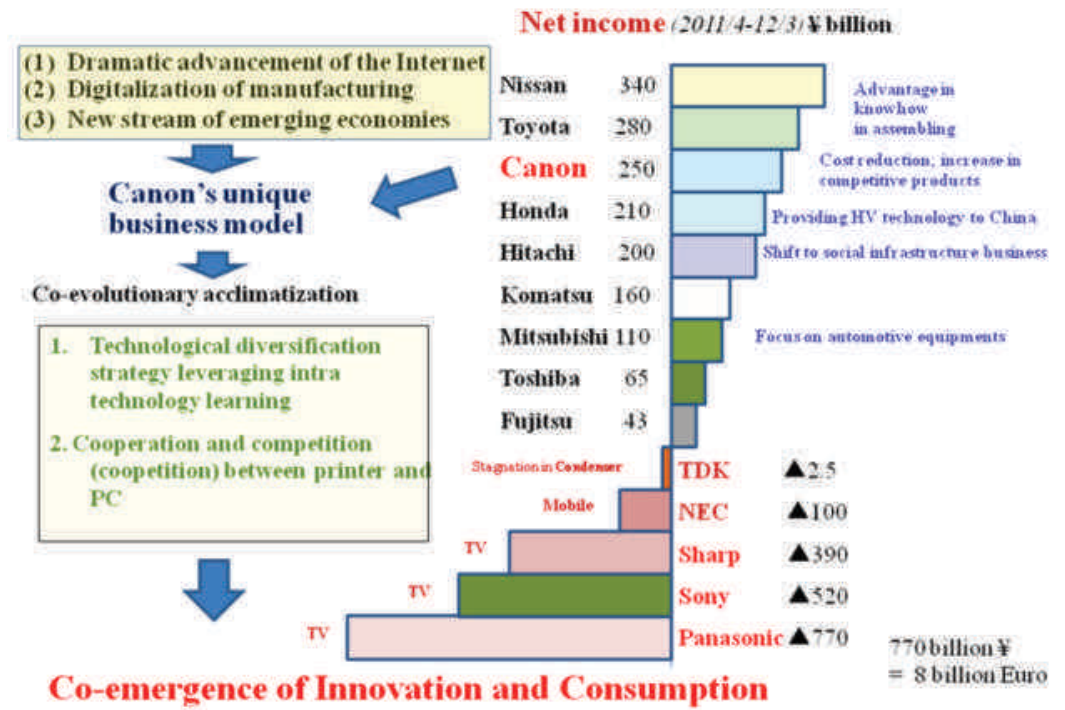

Figure 6: Bi-polarization of Leading High-technology Firms in Japan (2011) Sources: Annual report of respective firms.

\section{ASSESSMENT OF RESILIENCE IN GLOBAL ICT FIRMS}

Struck by these shocking observations, Fig. 7 assesses sustainability of highperformance in high R\&D intensive 18 firms $^{3}$ which demonstrated R\&D among matured ICT firms both in 2007 and 2010 (see Table 2) by examining sales, operating income and market capitalisation (market value of equity) over the period 2003-2010 among firms sustaining their top 100 position in the world. 
Watanabe, C.

Naveed, K.

Zhao, W.

\section{6}
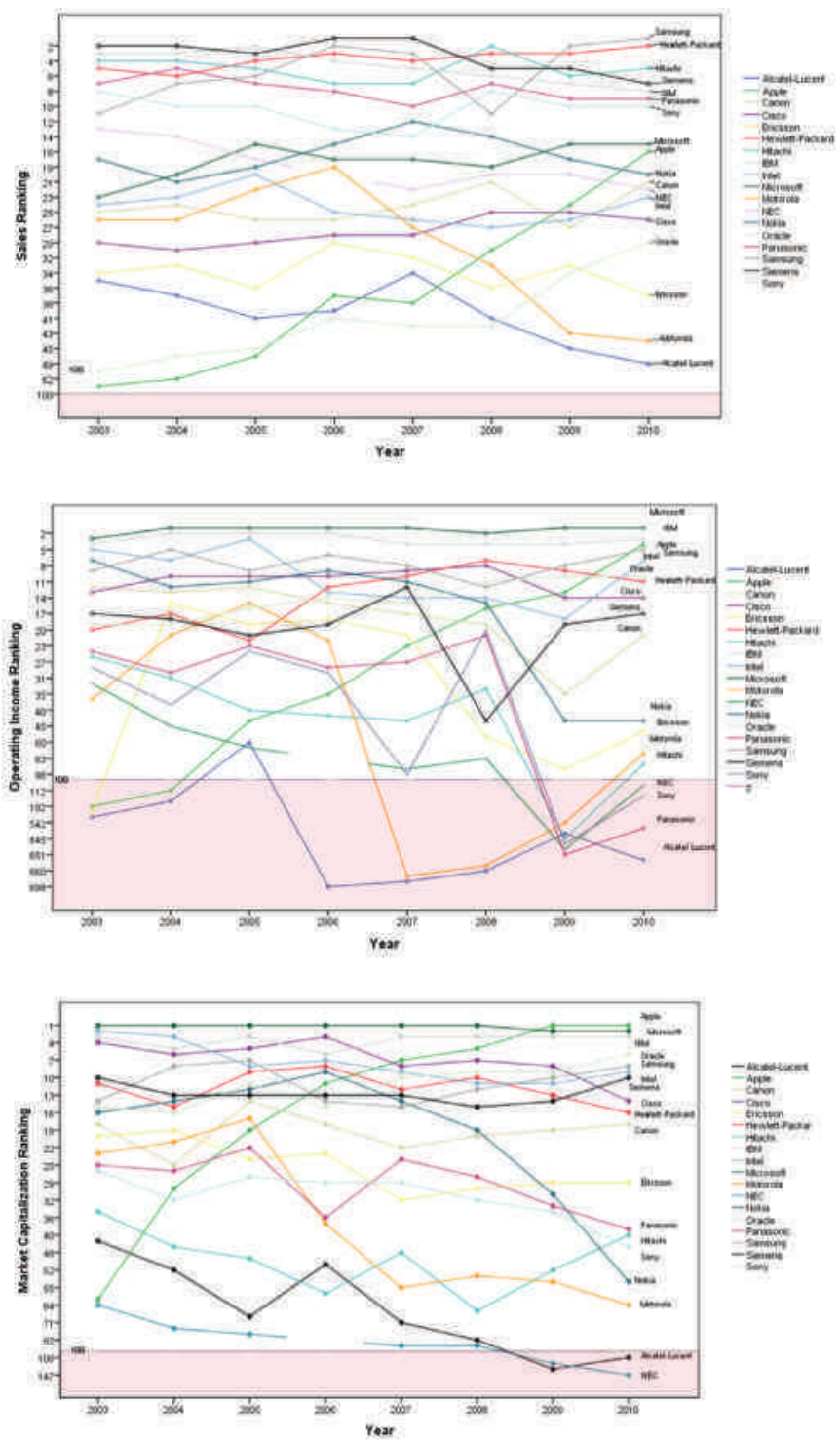

Figure 7: Sustainability of High-performance in High R\&D Intensive 18 Firms (2003-2010)

Source: Economics of Industrial Research and Innovation (EU, 2011)

Lessons from significant deficit beyond anticipation that Japan's leading global ICT firms experienced as a consequence of clinging to traditional efficiency oriented business model without paying careful attention to resilience against new stream suggest a significance of the assessment of sustainability from the view 
point of resilience (Watanabe, 2013).

Here resilience can be defined as "ability to transform external shocks into a springboard for further advancement by recovering from and adjusting smoothly through prompt and agile reaction" (Watanabe et al., 2003, Watanabe, 2009b, Ilmola et al., 2013). This concept prompts us with a significance of stability which is a function of constancy, persistence, resistance, elasticity and domain of attraction (Grimm and Wissel, 1997) leading to measuring the resilience of global ICT firms by means of frequency (FQ). In this case, frequency can be measured by counting the years when examinee firms sustain their top 100 position based on all factors of sales, operating income and market capitalization over the period 2003-2010. Firms, which satisfy this requirement for all 8 years can be appreciated based on FQ 8 while those, which failed to sustain any one factor for $\mathrm{n}$ years should be appraised as FQ (8-n). Since Panasonic and Sony lost their 100 position based on operating income in 2009 and 2010 due to Lehman shock in 2008, their FQ can be counted as 6 while Ericsson's FQ can be 7 as it lost operating income in 2003. Firms with FQ 8 can be classified as resilient firms while those with lower than FQ 7 should be classified as non-resilient firms.

Fig. 8 illustrates scheme in classifying resilient firms out of high R\&D intensive global ICT firms (R\&D matured ICT firms) and the result of the classification based on Fig. 7. 12 firms viz., as Microsoft, Samsung Electronics, Nokia, Intel, Siemens, Cisco Systems, IBM, Hitachi, Oracle, Canon, Hewlett-Packard and Apple can be classified under resilient firms while other 6 firms as Panasonic, Sony, Ericsson, Alcatel-Lucent, NEC and Motorola should be classified under non-resilient firms.

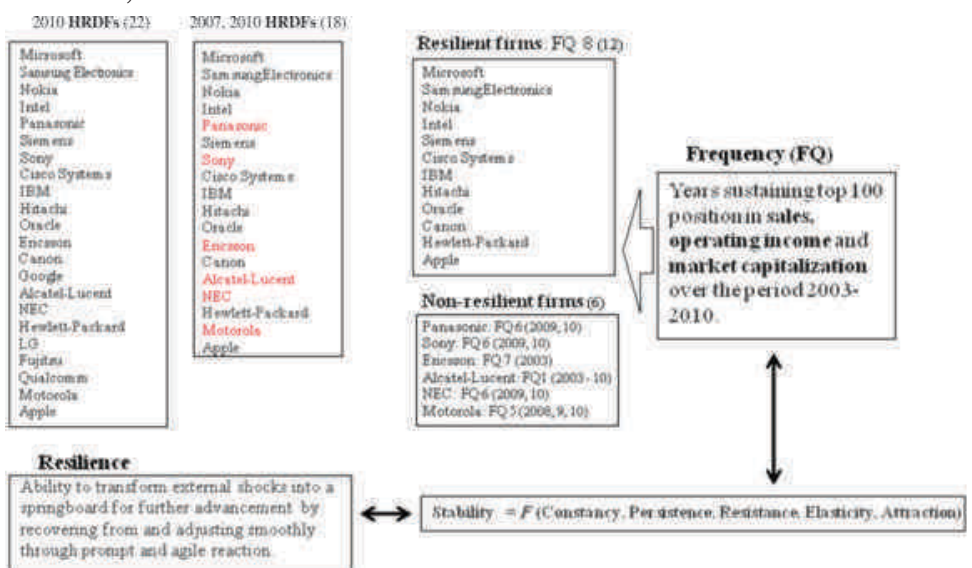

Figure 8: Scheme in Classifying Resilient Firms out of High R\&D Intensive Global ICT Firms (HRDFs).

Source: Industrial R\&D Investment Scoreboard (EU, annual issues). $a$ Figures in parenthesis in non-resilient firms indicate years when loosing top 100 firms position either R\&D, operating income or market capitalization.

Journal of Technology Management for Growing Economies, Volume 5, Number 1, April 2014
Institutional

Sources of

Resilience 
Watanabe, C. Naveed, K. Zhao, W.

\section{RESILIENT TECHNOPRENEURIAL STRUCTURE IN RESILIENT GLOBAL ICT FIRMS}

Based on the foregoing assessment, resilient technopreneurial structure in resilient global ICT firms are analyzed by comparing them with non-resilient firms.

\section{Analytical Framework}

Since market value of global ICT firms is subjected to its technology intensity, its profitability, market exploration power, global economic condition and external happening, provided that it is governed by technology intensity, profitability of R\&D, sales volume, market situation, and irregular factors, following equation can be depicted:

$$
\ln M C=a+b \ln \frac{T}{S}+c \ln \frac{O I}{R}+d \ln S+e \ln P M I+f D
$$

where $M C$ : market value of equity (market capitalization), $T$ : gross technology stock, $S$ : sales, $O I$ : operating income, $R$ : R\&D expenditure, $P M I$ : Purchasing Manager's Index ${ }^{4}, D$ : dummy variables corresponding to the irregular external happenings, and $a, b, c, d, e, f$ : coefficients.

Since $T \approx \frac{R}{\rho+g}, \quad T=T_{i}+Z_{s}=T_{i}\left(1+z \frac{T_{s}}{T_{i}}\right)$

where Ti: indigenous technology stock, Ts: technology knowledge stock, $z$ : assimilation capacity, : rate of obsolescence of technology, and $g$ : increasing rate of R\&D expenditure at the initial state of technology stock formation.

Direct contribution of technology stock to $M C$ can be depicted as follows:

$$
b \ln \frac{T}{S} \approx b(\ln T-\ln S)=b\left[\ln T_{i}\left(1+z \frac{T_{s}}{T_{x}}\right)-\ln S\right] \approx b \ln \frac{T_{i}}{S}+b z \frac{T_{s}}{T_{i}} \approx b \ln \frac{R}{S}+b z \frac{T_{s}}{T_{i}}-b \ln (\rho+g)
$$

Provided that $\rho+g$ is stable, integration of equations (1) and (2) leads to the following equation:

$\ln M C=a^{\prime}+b \ln \frac{R}{S}+b_{2} \frac{T_{s}}{T_{i}}+c \ln \frac{O I}{R}+d \ln S+e \ln P M I+f D$

where $a^{\prime}=a-b \ln (\rho+g)$ coefficient, and $b_{2}=b z$

Assimilation capacity can be measured by the following equation

$$
z=\frac{b_{2}}{b}
$$




\section{Empirical Analysis}

Based on the foregoing analytical framework, an empirical analysis was conducted by taking 10 selected firms, both with \& without resilient structure, out of 18 high R\&D intensive ICT firms. There are categorized in R\&D matured ICT firms both in 2007 and 2010.

Data are constructed by utilizing statistics from EU Industrial R\&D Investment Scoreboard, OECD, World Bank, World Economic Forum and also annual reports of respective firms.

To identify the indigenous technopreneurial structure of the firms which are to be analyzed, Fig. 9 compares R\&D intensity (R/S), operating income to sales $(\mathrm{OI} / \mathrm{S})$, and operating income to $\mathrm{R} \& \mathrm{D}(\mathrm{OI} / \mathrm{R})$ in 18 high $\mathrm{R} \& \mathrm{D}$ intensive ICT firms (R\&D matured ICT firms) in 2007 and 2010 (before and after the Lehman shock in 2008).
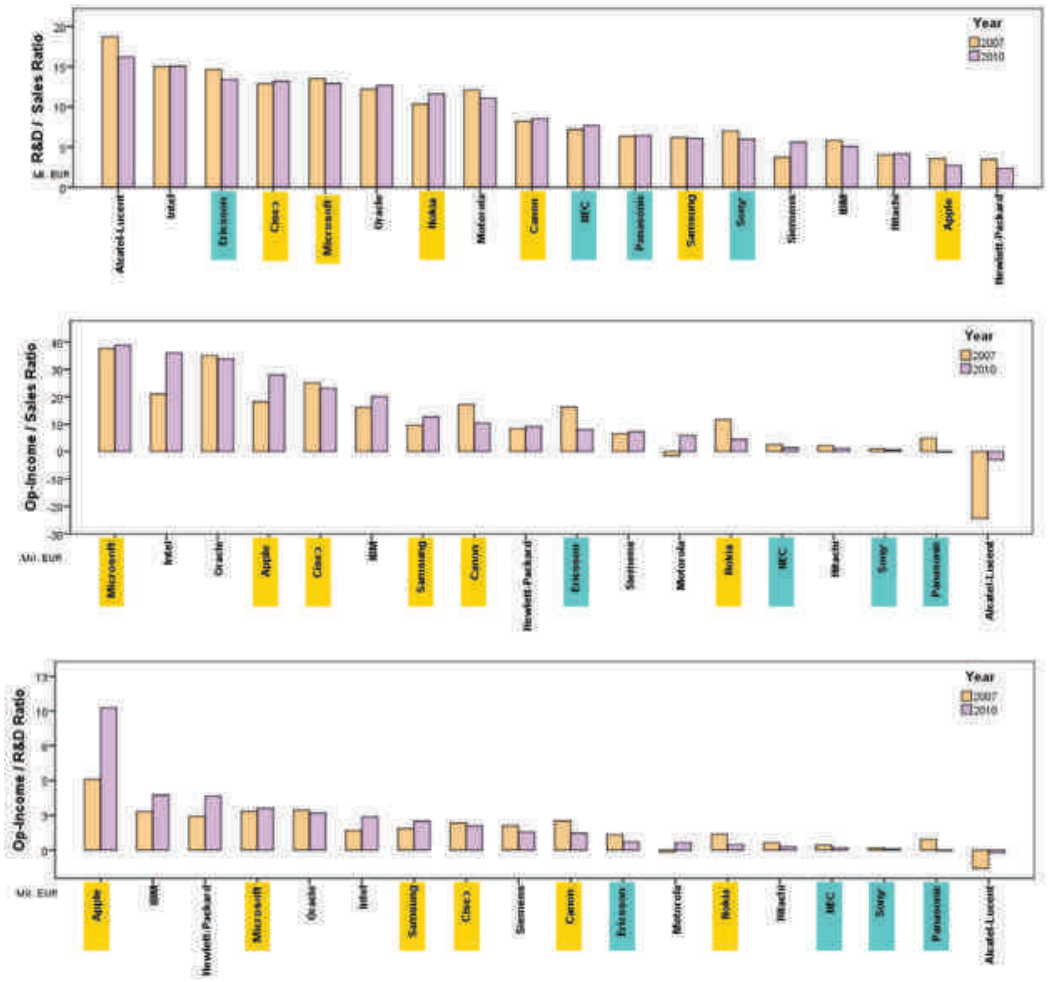

Figure 9: Comparison of R\&D Intensity, Operating Income to Sales, and Operating Income to R\&D in 18 High R\&D Intensive ICT Firms in 2007 and 2010 10 selected firms, which are analyzed include 6 resilient firms viz., Microsoft (US), Canon (Japan), Samsung (Korea), Apple (US), Cisco (US), Nokia
Institutional

Sources of

Resilience 
Watanabe, C. Naveed, K. Zhao, W.
(Finland) and 4 non-resilient firms as Panasonic (Japan), Ericsson (Sweden), NEC (Japan), Sony (Japan). Results of the analysis are presented in Table 3.

Table 3: Governing Factors of Market Value of Equity in 10 Selected Firms

$\ln M C=a+b \ln R / S+b_{2} T s / T i+c \ln O I / R+d \ln S+e \ln P M I+f D$

\begin{tabular}{|c|c|c|c|c|c|c|c|c|c|c|}
\hline Firm & $a$ & $b$ & $b_{2}$ & $c$ & $d$ & & $f$ & $\operatorname{adj} . R^{2}$ & $z=b_{2} / b$ & $e$ \\
\hline Microsoft & 7.835 & 6.813 & 0.008 & 3.141 & 0.722 & 1.755 & -0.549 & 0.960 & \multirow[b]{2}{*}{$0.12 \times 10^{-2}$} & \multirow{2}{*}{$\begin{array}{l}(1991,2011, \\
2000,2010, \\
1997) \\
=1 \text { Others }=0\end{array}$} \\
\hline (1991-2011) & $2.93\left(*_{1}\right)$ & $8.71\left({ }^{*}{ }_{1}\right)$ & $132(*)$ & $7.89\left({ }_{1}\right)$ & $6.35\left(*_{1}\right)$ & $2.74\left({ }_{2}\right)$ & $-3.70\left(*_{2}\right)$ & & & \\
\hline Canon & -10.256 & 1.565 & $0.095^{4}$ & 0.214 & 1.754 & 1.037 & -0.647 & \multirow[b]{2}{*}{0.915} & \multirow[b]{2}{*}{$6.07 \times 10^{-2}$} & \multirow[b]{2}{*}{$\begin{array}{l}(2012)=1 \\
\text { Others }=0\end{array}$} \\
\hline$(1994-2012)$ & $-1.82\left(*_{3}\right)$ & $2.06\left({ }_{2}\right)$ & $5.60(*)$ & $1.19\left(*_{4}\right)$ & $4.84\left(*_{1}\right)$ & $1.74\left(*_{3}\right)$ & $-3.00\left(*_{1}\right)$ & & & \\
\hline Samsung & -0.587 & 3.269 & 0.076 & 0.409 & 1.734 & - & -1.328 & 0.970 & \multirow{2}{*}{$2.32 \times 10^{-2}$} & \multirow{2}{*}{$\begin{array}{l}(1998)=1 \\
\text { Others }=0\end{array}$} \\
\hline (1998-2012) & $-0.29\left(*_{5}\right)$ & $3.64\left({ }_{1}\right)$ & $2.93(*)$ & $3.30\left(*_{1}\right)$ & $5.70\left(*_{1}\right)$ & - & $-6.71\left(*_{1}\right)$ & & & \\
\hline Apple & -10.166 & 4.877 & 0.033 & 0.594 & 3.346 & - & 0.726 & 0.917 & \multirow[b]{2}{*}{$0.68 \times 10^{-2}$} & \multirow{2}{*}{$\begin{array}{l}(1991)=1 \\
\text { Others }=0\end{array}$} \\
\hline (1990-2012) & $-3.74\left(*_{1}\right)$ & $2.59\left(*_{2}\right)$ & $3.99(*)$ & $2.77\left(*_{2}\right)$ & $4.68\left(*_{1}\right)$ & - & $1.22\left(*_{4}\right)$ & & & \\
\hline Cisco & -0.184 & 2.673 & - & 1.148 & 0.691 & 2.404 & 1.095 & 0.936 & & \multirow{2}{*}{$\begin{array}{l}(1995,1996, \\
1998, \\
1999,2000)=1 \\
\text { Others }=0\end{array}$} \\
\hline$(1990-2012)$ & $-0.03\left(*_{5}\right)$ & $2.17(*)$ & - & $1.87(* 3)$ & $5.97\left(*_{1}\right)$ & $1.72\left(*_{3}\right)$ & $5.06(*)$ & & & \\
\hline Nokia & 7.284 & 1.884 & - & 0.914 & 0.743 & - & 1.279 & 0.961 & & \multirow{2}{*}{$\begin{array}{l}(1999,2000, \\
2001)=1 \\
\text { Others }=0\end{array}$} \\
\hline (1991-2012) & $2.45\left(*_{4}\right)$ & $3.05\left({ }_{2}\right)$ & - & $8.45\left({ }_{1}\right)$ & $4.62\left(*_{1}\right)$ & - & $6.86\left(*_{1}\right)$ & & & \\
\hline Panasonic & 2.460 & 1.456 & - & 0.451 & 0.540 & 1.605 & -0.662 & 0.536 & & \multirow{2}{*}{$\begin{array}{l}(2004,2010, \\
2012) \\
=1 \\
\text { Others }=0\end{array}$} \\
\hline$(1995-2012)$ & $0.38\left(*_{5}\right)$ & $1.51\left(*_{4}\right)$ & - & $3.44\left({ }_{1}\right)$ & $1.14\left({ }_{4}\right)$ & $1.44\left(*_{4}\right)$ & $-3.26\left(*_{1}\right)$ & & & \\
\hline Ericsson & 13.635 & 1.381 & - & 0.271 & -0.659 & 1.600 & 0.961 & 0.597 & & \multirow{2}{*}{$\begin{array}{l}(1995,1999, \\
2000,2012)=1 \\
\text { Others }=0\end{array}$} \\
\hline (1991-2012) & $2.24\left({ }_{2}\right)$ & $1.16(*)$ & - & $1.53\left(*_{4}\right)$ & $-3.404\left(*_{1}\right)$ & $1.202\left({ }^{*}\right)$ & $4.51(*)$ & & & \\
\hline NEC & -8.300 & -1.630 & -0.022 & - & 1.274 & - & - & 0.445 & $1.35 \times 10^{-2}$ & \\
\hline (1990-2012) & $-1.88\left(*_{3}\right)$ & $-2.32\left(*_{2}\right)$ & $2.92\left(*_{1}\right)$ & - & $3.15\left(*_{1}\right)$ & - & - & & & \\
\hline Sony & -6.648 & -1.498 & -0.142 & -0.18 & 1.349 & - & 0.998 & 0.733 & \multirow[b]{2}{*}{$9.47 \times 10^{-2}$} & \multirow[b]{2}{*}{$\begin{array}{l}(1999)=1 \\
\text { Others }=0\end{array}$} \\
\hline (1990-2012) & $-1.93\left(*_{3}\right)$ & $-1.90\left(*_{3}\right)$ & $2.62\left(*_{2}\right)$ & $-1.50\left(*{ }_{4}\right)$ & $5.21\left(*_{1}\right)$ & - & $3.15(*)$ & & & \\
\hline
\end{tabular}

Figures in the second line of the respective column indicate t-statistics. ${ }_{1}{ }_{1}{ }_{2}{ }_{2}{ }_{3}$ and ${ }_{4}$ indicate significant at the $1 \%, 5 \%, 10 \%$ and $20 \%$ level, respectively. ${ }_{5}$ indicate more than $20 \%$ level only for constant term. 
Fig. 10 compares resilient structure in 10 firms examined by highlighting Institutional sources of resilience through comparison of elasticity of R/S (R\&D intensity), OI/R (operating income to R\&D: R\&D profitability), $S$ (sales volume) and Sources of PMI (Purchasing Manager's Index), and also spillover coefficient.

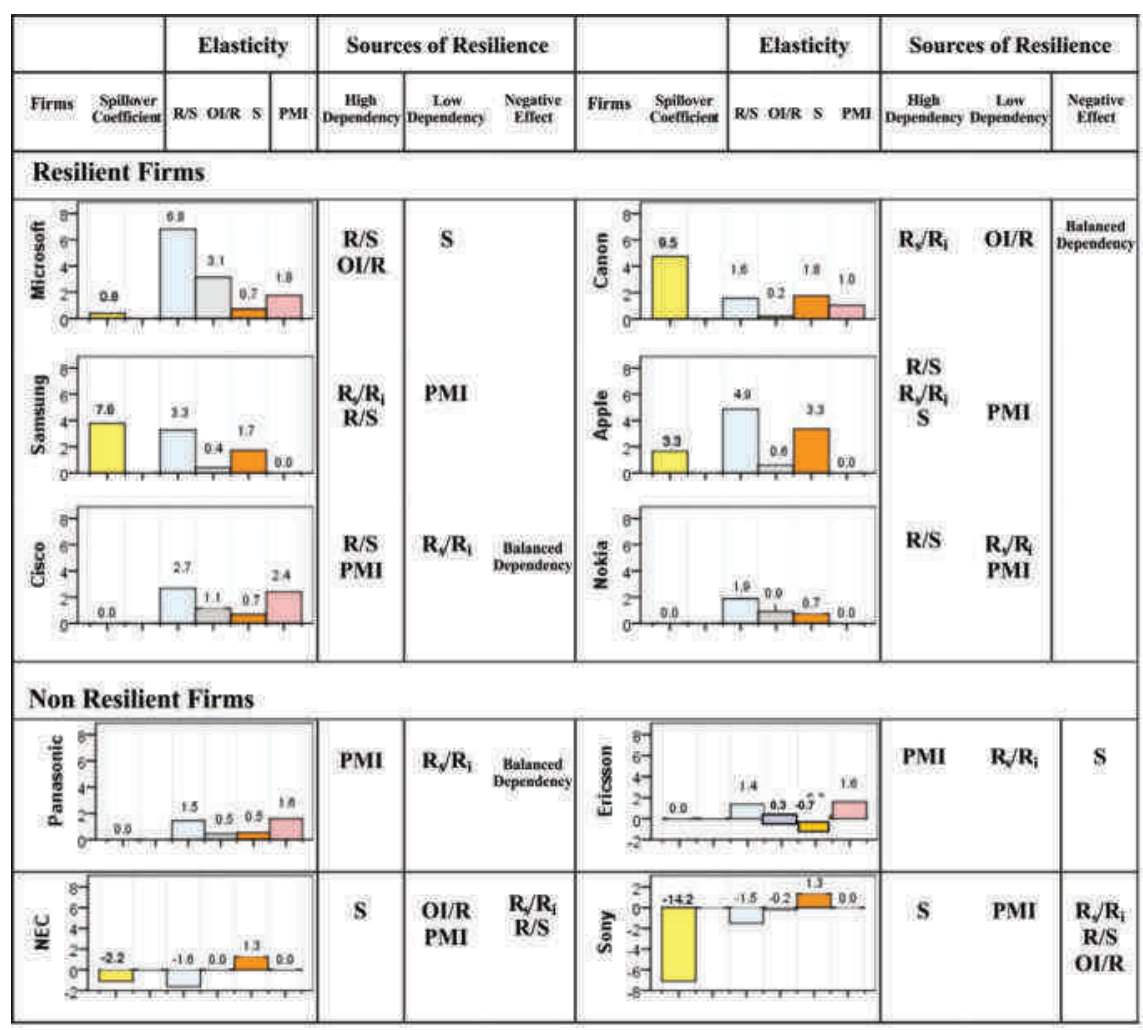

Figure 10: Comparison of Resilient Structure in Selected Firms

Noteworthy structural characteristics leading to resilient and non-resilient firms are summarized as follows:

\section{1) RESILIENT FIRMS}

i. Microsoft demonstrates high dependency on R\&D intensity $(\mathrm{R} / \mathrm{S})$ and profitability of R\&D (OI/R) while low dependency on sales volume (S). This structure suggests that, as far as high profitable $R \& D$ continues that contributes to operating income (OI) increase, market value can be sustained independent of sales.

ii. Canon demonstrates extremely high dependency on assimilation of spillover technology, while low dependency on profitability of R\&D (OI/R). It also 
Watanabe, C. Naveed, K. Zhao, W.

maintains a well balanced dependency on all factors contributing to market value.

This structure suggests that effective utilization of external resources in innovation while minimizing own risk for high profitable $R \& D$ can be the source for resilient market value creation. Well balanced structure supports this resilience.

iii. Samsung demonstrates high dependency on assimilation of spillover technology and R\&D intensity $(\mathrm{R} / \mathrm{S})$ while not depending on market situation (PMI). This structure suggests that hybrid management of technology between indigenous R\&D and assimilation spillover technology, while not depending on external market situation can also be the source for resilient market value creation.

iv. Apple demonstrates similar structure as Samsung, supporting the significance of such structure for resilient market value creation. It demonstrates high dependency on $R \& D$ intensity $(R / S)$ and sales volume (S) while low dependency on profitability of R\&D (OI/R) and no dependency on market situation (PMI). It depends also on assimilation of spillover technology. Given its high level of profitability of $R \& D(O I / R)$ and low level of $R \& D$ intensity $(\mathrm{R} / \mathrm{S})$ this structure demonstrates efficient and resilient structure as far as its sales volume (S) maintains competence in the market.

v. Cisco demonstrates high dependency on $R \& D$ intensity $(R / S)$ and market situation (PMI) while not depending on spillover technology as similar to Canon; it also maintains well balanced dependency on all factors contributing to market value. This structure suggests that balanced dependency between internal R\&D effort and external market situation can lead to resilient market value creation.

vi. Nokia demonstrates high dependency on R\&D intensity (R/S), while not depending on spillover technology and market situation (PMI). This structure suggests that sustainable $R \& D$ intensity $(R / S)$ with reasonable profitability of $R \& D(O I / R)$ function can be a source of resilient market value creation. However, contrary to preceding structures, fragility cannot be removed from this structure.

\section{2) NON RESILIENT FIRMS}

i. Panasonic demonstrates similar structure as Cisco, while its dependency on profitability of $R \& D(O I / R)$ is lower than Cisco. This suggests that resilience of this structure can turn out to be non-resilient upon decreasing dependency on profitability of R\&D (OI/R).

Journal of Technology Management for Growing Economies, Volume 5, Number 1, April 2014 
ii. Ericsson demonstrates negative dependency on sales volume (S: sales increase results in decrease in market value). This implies its products Sources of have matured in the market and necessitate new attractive innovation.

iii. NEC demonstrates negative dependency on spillover technology and $R \& D$ intensity $(R / S)$, while not depending on profitability of $R \& D$ $(\mathrm{OI} / \mathrm{R})$ and market situation (PMI), It only depends on sales volume (S). This implies that its R\&D does not stimulate market value neither assimilate the spillover technology, which is attractive enough to increase its market value.

iv. Sony demonstrates negative dependency not only on spillover technology, and $R \& D$ intensity $(R / S)$ but also on profitability of R\&D (OI/R) while not depending on market situation (PMI). Similar to NEC, it depends only on sales volume (S). This implies that its $R \& D$ has lost attractiveness in the market resulted in loosing the increase in operating income (OI) leading to an increase market value.

\section{(3) IMPLICATIONS FOR RESILIENT MARKET VALUE CREATION}

Foregoing analysis suggests the following implications for resilient market value creation.

i. Dependency on high $R \& D$ profitability $(\mathrm{OI} / \mathrm{R})^{5}$ while restraining its elasticity enables efficient functionality development while minimizing risk taking leading to resistant market value creation [Apple model].

ii. Effective utilization of external resources in innovation also enables minimum dependency on high risk R\&D while maximizing the benefit of open innovation and leads to resilient market value creation [Canon model].

iii. Hybrid management of technology between indigenous R\&D and assimilation of spillover technology can lead to resilient market value creation [Samsung model].

iv. While balanced dependency between internal R\&D effort and external market situation can lead to resilient market value creation [Microsoft], it can be turn out to be non-resilient upon decreasing dependency on profitability of R\&D (OI/R) [Panasonic].

v. Matured products/services as well as $R \& D$ which have lost attractiveness in the market may result in negative dependency and non-resilient market value creation [Ericsson, NEC, Sony].

Drivers for resilience in resilient firms and their mechanism for resilience can be summarized as Table 4 . 
Watanabe, C. Naveed, K.

Zhao, W.
Table 4 : Drivers for Resilience in Resilient Firms

\begin{tabular}{|l|l|l|}
\hline Resilient firms & Drivers for resilience & $\begin{array}{l}\text { Mechanism for resil- } \\
\text { ience }\end{array}$ \\
\hline Apple & $\begin{array}{l}\text { Dependency on high R\&D prof- } \\
\text { itability while restraining its } \\
\text { elasticity }\end{array}$ & $\begin{array}{l}\text { Efficient functional- } \\
\text { ity development while } \\
\text { minimizing risk taking }\end{array}$ \\
\hline Canon & $\begin{array}{l}\text { Effective utilization of external } \\
\text { resources in innovation }\end{array}$ & $\begin{array}{l}\text { Minimum dependency } \\
\text { on high risk R\&D while } \\
\text { maximizing the benefit } \\
\text { of open innovation }\end{array}$ \\
\hline Samsung & $\begin{array}{l}\text { Hybrid management of tech- } \\
\text { nology between indigenous } \\
\text { R\&D and assimilation of } \\
\text { spillover technology }\end{array}$ & $\begin{array}{l}\text { Synergy effect for } \\
\text { efficient functional- } \\
\text { ity development and } \\
\text { minimum risk taking }\end{array}$ \\
\hline Microsoft & $\begin{array}{l}\text { Balanced dependency be- } \\
\text { tween internal R\&D effort } \\
\text { and external market situation }\end{array}$ & $\begin{array}{l}\text { Harness the vigor of } \\
\text { market while main- } \\
\text { taining indigenous } \\
\text { vigor }\end{array}$ \\
\hline
\end{tabular}

\section{STRUCTURAL SOURCE OF THE TRAP OF ICT ADVANCEMENT}

Analysis in the preceding section demonstrates that certain $R \& D$ matured resilient ICT firms manage to maintain sustainable growth while the majority of R\&D matured ICT firms suffer "the great stagnation" (Cowen, 2011) because of the trap of ICT advancement as reviewed under the heading 'Great Stagnation in ICT Matured Economics'. Success in resilient ICT firms can largely be attributed to efficient functionality development by maximizing $R \& D$ profitability (e.g., Apple) and open innovation (e.g., Canon) while minimizing the possibility of risk taking by restraining elasticity of such profitability (e.g. Apple) and depending on spillover effect (e.g. Canon).

Given that these business model enables resilient firms to maintain sustainable growth despite fatal nature of the great stagnation subsequent to the high dependency on the advancement of ICT centered by the dramatic

Journal of Technology Management for Growing Economies, Volume 5, Number 1, April 2014 
advancement of the Internet, following two faces as illustrated in Fig. 11 can be postulated as a possible source of the trap of ICT advancement.

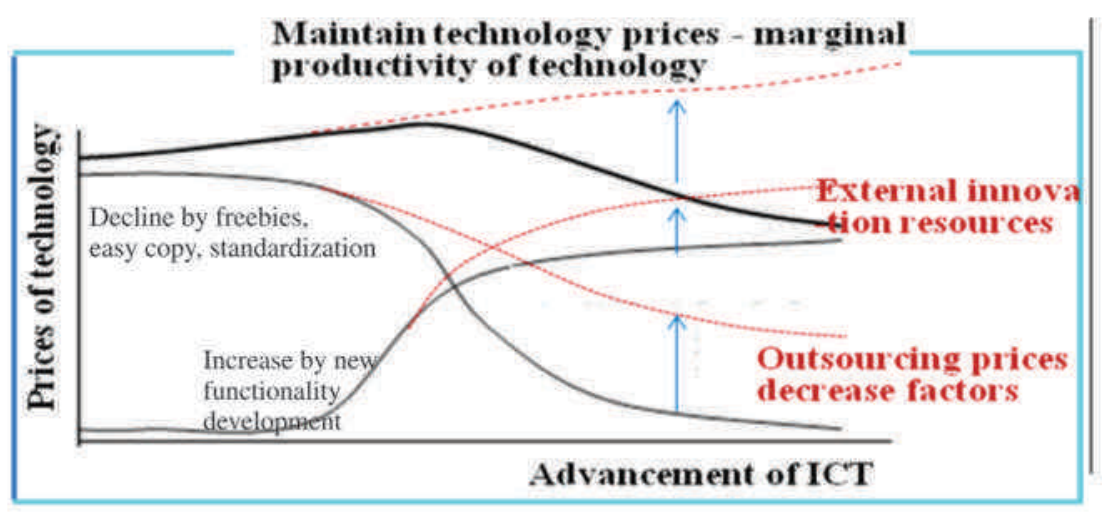

Institutional

Sources of Resilience

\section{Figure 11: ICT's Identical Two Faces}

Fig. 11 illustrates ICT's identical two faces. Advancement of ICT generally contributes to enhanced price of technology by increasing new functionality development. However, the dramatic advancement of the Internet reacts to decline price of technology due to its nature by freebies, easy copy and mass standardization. Consequently, price of technology in highly R\&D intensive economies may change to declining trend resulting in decreasing their growth rate as outlined in Fig. 12. This can be the structural source of the trap of ICT advancement compelling ICT advanced nations/firms suffering a vicious cycle between advancement of ICT and its marginal productivity ${ }^{6}$ decrease as reviewed in section 2 .

Production function and growth rate of ICT firms can be depicted as follows:

$$
\begin{aligned}
& \text { Contribution by } \\
& \text { traditional factors technology (TFP) } \\
& S=F(X, T) \quad \frac{\Delta S}{S}=\left\{\left(\frac{\partial S}{\partial X} \cdot \frac{X}{S}\right) \frac{\Delta X}{X}+\left(\frac{\partial S}{\partial T} \cdot \frac{T}{S}\right) \frac{\Delta T}{T}\right. \\
& \text { Since } \frac{\partial S}{\partial T}=\frac{P_{5}}{P_{5}}, T F P=\frac{P_{7}}{P_{5}} \cdot \frac{R}{S} \\
& \frac{P_{T}}{P_{S}} \cdot \frac{R}{S} \rightarrow p_{T} \text { decrease } \rightarrow \frac{\Delta S}{S} \text { decrease }
\end{aligned}
$$

Figure 12: Scheme of the Great Stagnation due to the Decrease in Technology Price 
Watanabe, C. Naveed, K. Zhao, W.

Given the foregoing circumstances, ICT firms endeavor should focus on accelerating price increase by means of successive efficient new functionality development while minimizing price decrease factors by outsourcing them to other parties.

Noteworthy accomplishments demonstrated by resilient global ICT firms as analyzed in the preceding section support this postulate and provide us constructive suggestions supportive to constructing new business model satisfying both efficiency and resilience in a global competitive market.

These accomplishments suggest the following co-evolutionary acclimatization system that enables both ICT advanced and growing economies to harness the vigor of counterparts. While R\&D matured ICT firms enable further advancement of ICT, it results in declining its productivity. Thus, such advancement should be addressed with the advancement of R\&D increasing ICT firms which enjoy a virtuous cycle between its advancement and productivity increase leading to sustainable growth as reviewed in Fig. 5 if its ICT advancement turns out to enabling position.

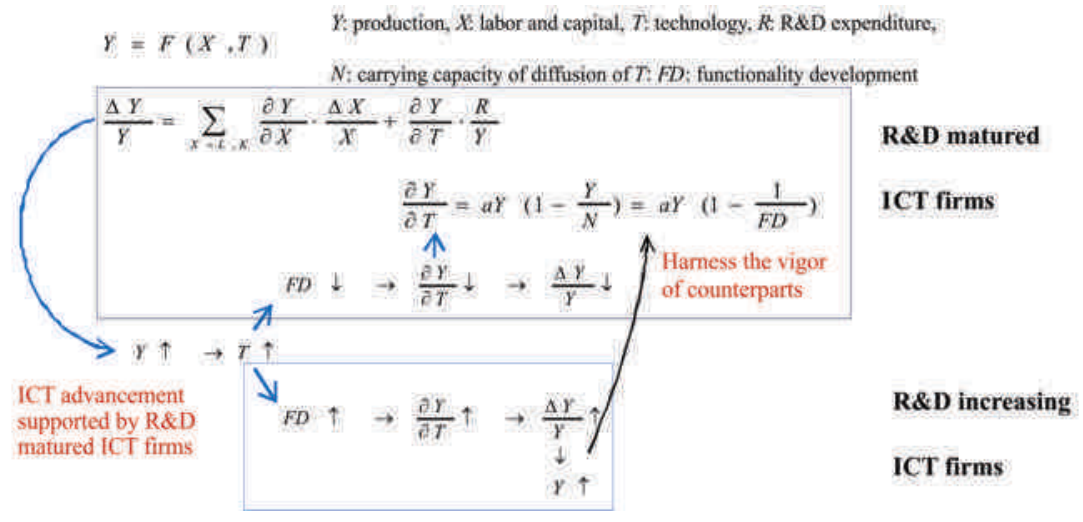

Figure 13: Scheme of Co-evolutionary Acclimatization in Global ICT Firms

\section{LESSONS FROM RESILIENT MODEL}

\section{ICT Advanced Economies: A case of Singapore}

As reviewed in section 3, contrary to conspicuous economic growth in ICT growing economies, GDP growth rates in countries among ICT advanced economies have demonstrated the great stagnation except for Singapore.

Sources of Singapore's resilient development trajectory can be observed in its NEWater (recycled water) development dynamism as illustrated in Fig. 14. Securing water is a crucial survival strategy for Singapore (Chew et al., 2010). In order to accomplish this survival strategy, Singapore endeavored to explore technology driven water starting from importing advanced

Journal of Technology Management for Growing Economies, Volume 5, Number 1, April 2014 
membrane technology from USA and Japan (Phase 1). Then it endeavored to transit from learning to indigenous technology development (Phase 2). It further endeavored to accelerate exporting developed indigenous technology (Phase 3 ) and co-evolutionary acclimatization of global best practices through exporting activities (Phase 4).

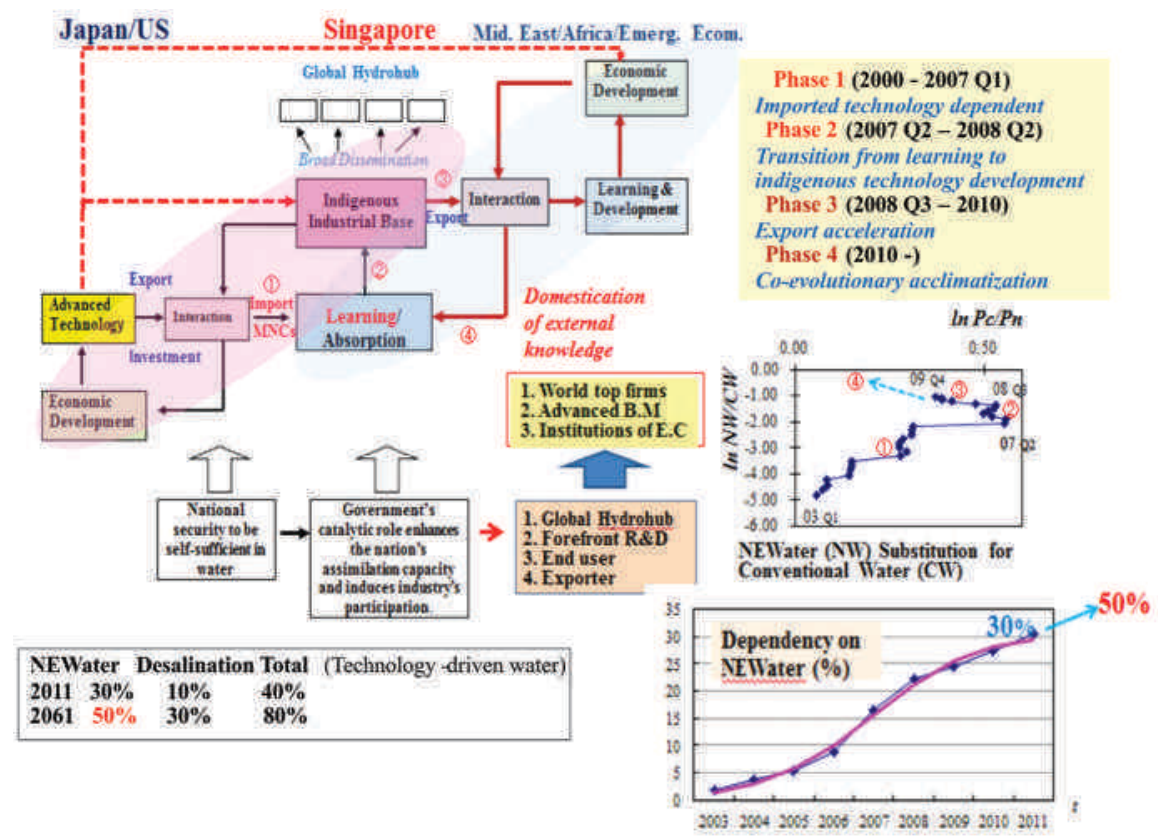

Institutional

Sources of

Resilience

Figure 14: NEWater Development Dynamism in Singapore

Source: Chew et al (2010)

Based on such a stepwise endeavor Singapore succeeded in sourcing $40 \%$ of water through technology driven water $30 \%$ on NEWater and $10 \%$ on desalination). It attempts to increase such dependency to double by 2061 ( $50 \%$ on NEWater and $30 \%$ on desalination).

Through the course of accomplishing such survival strategy Singapore has created dual innovation-consumption co-emergence structure which can be considered the source enabling it as exceptional sustainable growth despite bi-polarization structure resulting in stagnating sustainable growth in ICT advanced economies as reviewed in Fig. 5.

\section{Global ICT Firms}

\section{(1) Apple}

As reviewed in section 3, Apple depends largely on high R\&D profitability 
Watanabe, C. Naveed, K. Zhao, W.

$(\mathrm{OI} / \mathrm{R})$ while restraining its elasticity. This structure enables acceleration of price increase by means of successive efficient new functionality development while minimizing price decrease factors by outsourcing them to other parties as postulated in the preceding section as effective strategy in overcoming the trap of ICT advancement.

Fig. 15 illustrates this business model. Apple focuses its own resources on high value added business such as design, planning, marketing and after-service while entrusting manufacturing which is relatively adds lower value and higher risk to Japan and EMS thereby maximizing the merit of international division and learning and absorption effects. Based on this strategy it has succeeded to construct co-evolutionary acclimatization dynamism between comparative advantage in its indigenous strength and that of external resources leading to harness the vigor of ICT growing economies.

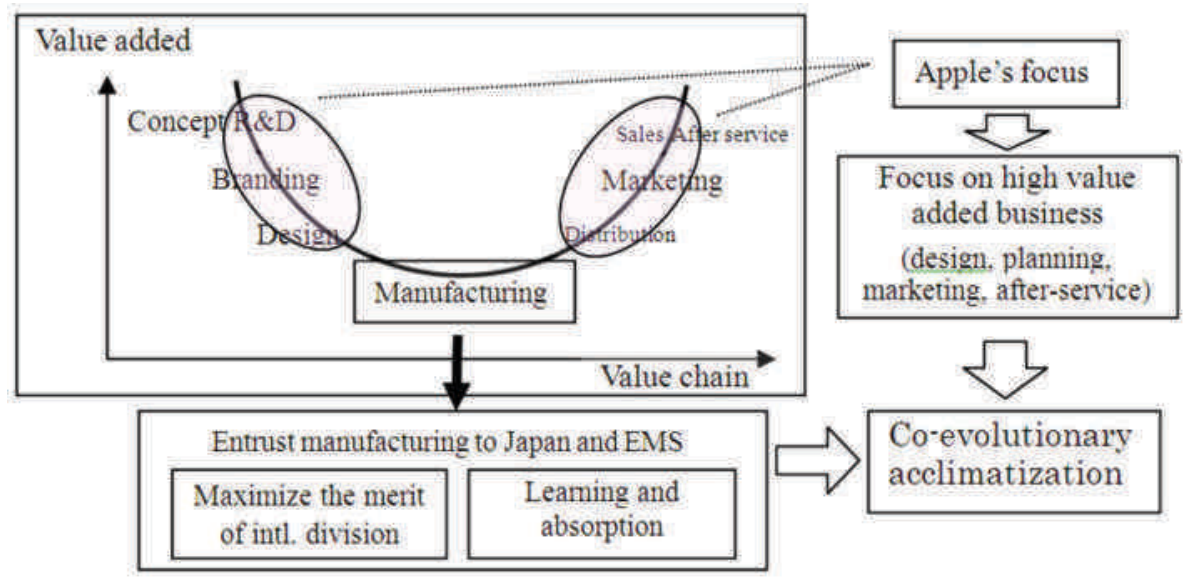

Figure 15: Apple's Business Model in Overcoming the Trap of ICT Advancement

\section{(2) Canon}

As compared in Fig. 6, notwithstanding new beyond anticipation stream as dramatic advancement of the Internet, digitalization of manufacturing, new stream of emerging economies, and growing anger of consumers that impacted its rival firms as Panasonic, Sony and Sharp resulting in suffering them significant deficits, Canon has maintained sufficient profits. This can be attributed to its unique business model based on co-evolutionary 
acclimatization strategy.

Canon's identical business model starts from its technological diversification strategy as illustrated in Fig. 16 (Watanabe, Lei and Ouchi, 2009).

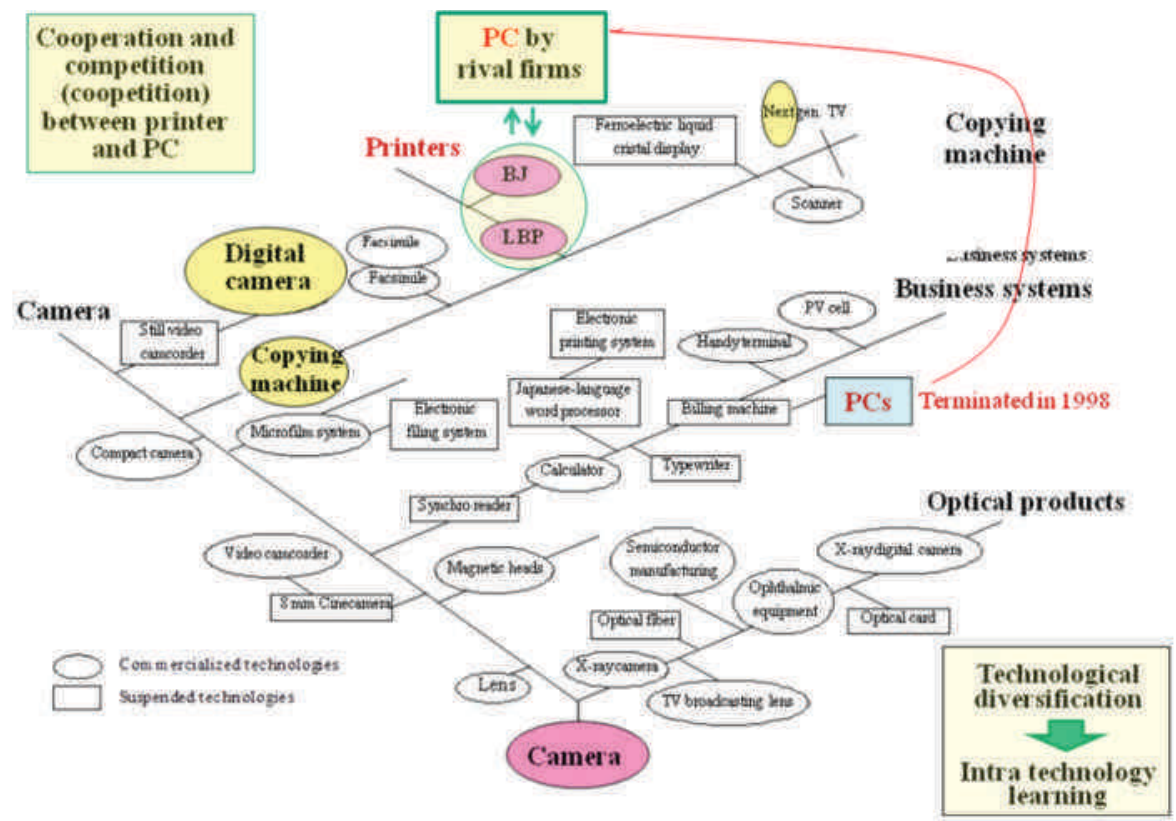

Figure 16: Canon's Technological Diversification Strategy

Starting from camera, Canon endeavored technological diversification strategy inducing intra technology learning such as coping machine, printers and digital camera.

Another noteworthy strategy is coopetition - cooperation and competition strategy. While Canon succeeded to develop market leading printers, it terminated PCs production in 1998 and provides opportunity to utilize attractive printers essential for the advancement of PCs to rival firms as NEC, Fujitsu, Sony and Toshiba. Through such cooperation and competition: coopetition strategy by means of attractive printers, crystal of intra technology learning, Canon has been able to obtain external learning, crystal of PCs technology developed by rival firms thereby constructed a virtuous cycle between its printers and rival firms PCs as illustrated in Fig. 17. 
Watanabe, C.

Naveed, K.

Zhao, W.

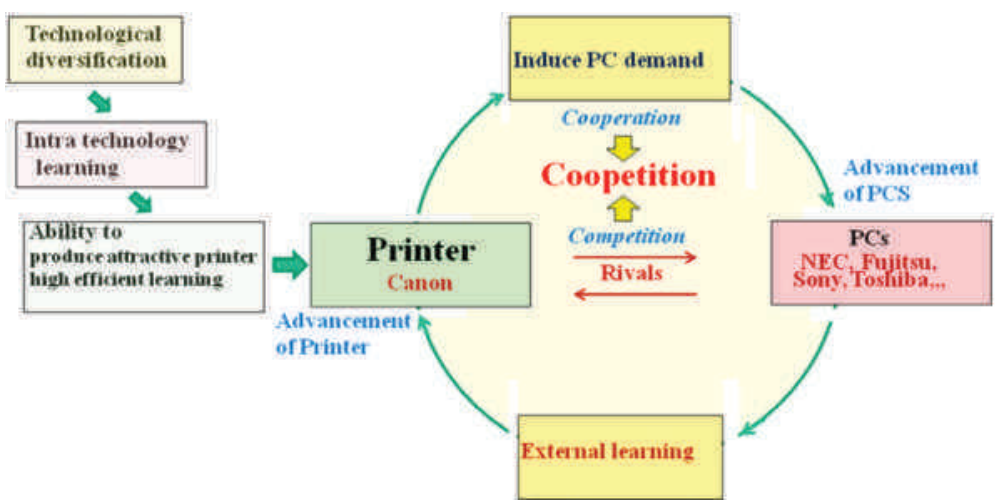

Figure 17; Virtuous Cycle between Canon Printers and PCs

In addition to such a virtuous cycle, Canon endeavored to harness the vigor of mobile phones development in consumers market. While Canon has never involved in mobile phones handset development, it can harness the vigor in the market activated by its attractive digital camera. In response to activated demand in the market rival firms (majority of them are PC producers and users of Canon's printers) endeavors development of advanced handsets which can be learned by Canon through coopetition between printers and PCs. Fig. 18 demonstrates this dynamism in co-emerging innovation and consumption through "in-vitro fertilization."

Based on the foregoing stepwise endeavor as individual technology, intratechnology learning, coopetition and in-vitro fertilization, Canon established unique business model in co-emerging innovation and consumption as demonstrated in Fig. 19. This is similar to Singapore's innovation-consumption co-emergence structure and can be considered the source of its resilience against beyond anticipation issues as demonstrated in Fig. 6.

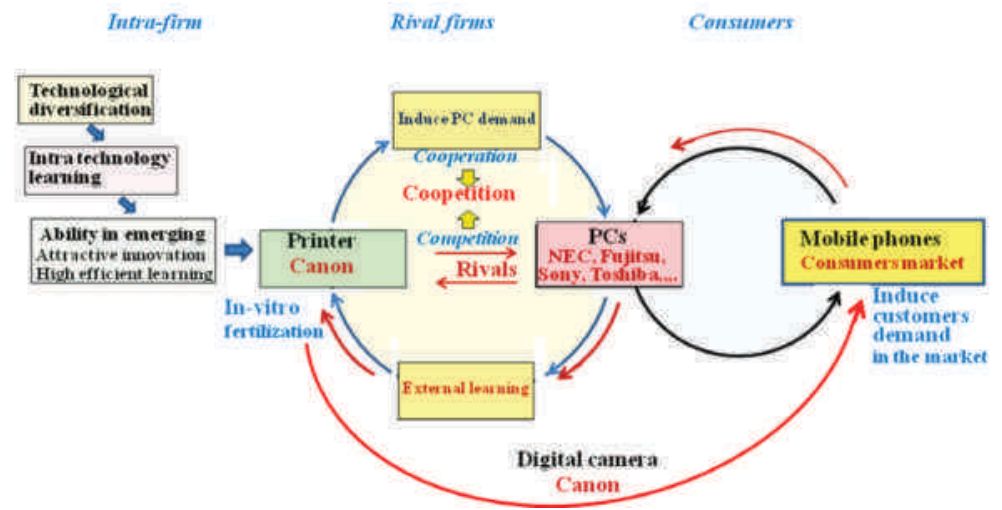

Figure 18: Dynamism in Co-emerging Innovation and Consumption - In-vitro Fertilization

Journal of Technology Management for Growing Economies, Volume 5, Number 1, April 2014 


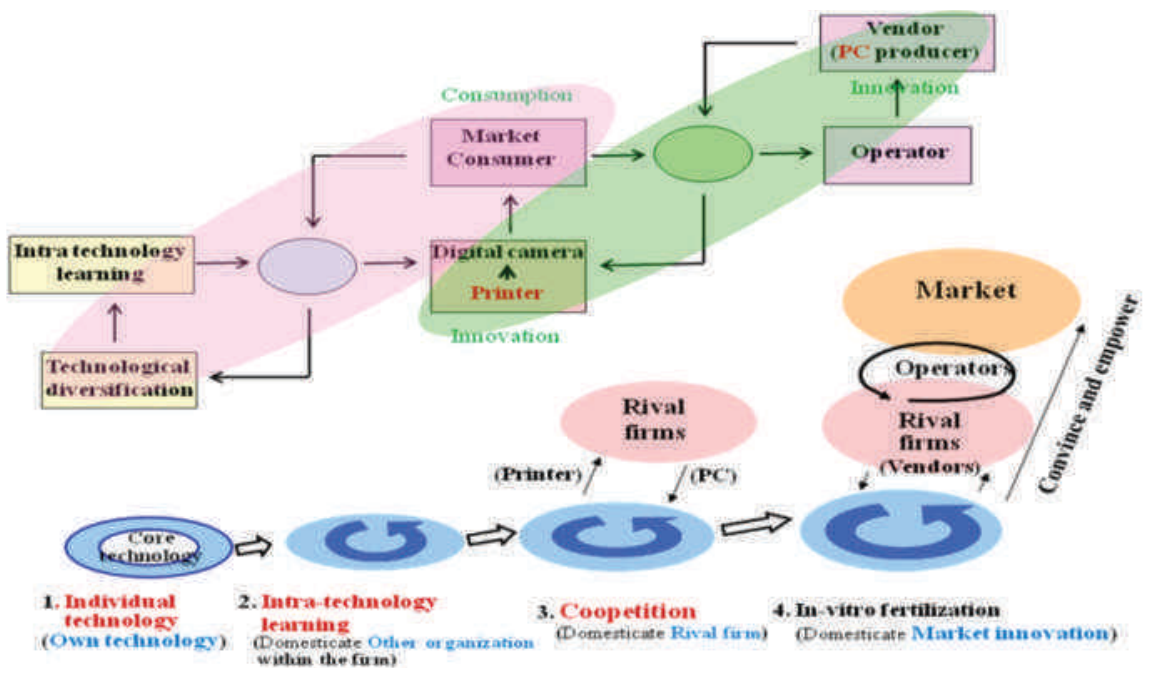

Institutional

Sources of

Resilience

Figure 19: Canon's Business Model in Co-emerging Innovation and

Consumption

\section{CONCLUSION}

In light of the significant impacts on global economy both nations and firms derived from the dramatic advancement of information and communication technology (ICT), particularly bi-polarization between ICT advanced and growing economies compelling a vicious cycle between ICT advancement and its productivity decline in the former economies, its institutional sources of resilience were analyzed.

Based on an empirical analysis comparing technopreneurial performance in world top 500 ICT firms by market value, sales and profit over the last decade, resilient firms maintaining top 100 position in the world based on all three factors over the period under study were identified.

An empirical analysis identifying governing factors to resilient market creation was conducted focusing on 10 selected high R\&D intensive ICT firms both with resilient and non-resilient structure.

Based on this analysis, structural sources of ICT trap was elucidated.

Noteworthy findings include

(i) Dependency on high $\mathrm{R} \& \mathrm{D}$ profitability $(\mathrm{OI} / \mathrm{R})$ while restraining its elasticity enables efficient functionality development while minimizing risk taking leading to resilient market value creation .

(ii) Effective utilization of external resources in innovation also enables minimum dependency on high risk R\&D while maximizing the benefit of 
Watanabe, C. Naveed, K. Zhao, W.

open innovation and leads to resilient market value creation.

(iii) Hybrid management of technology between indigenous $R \& D$ and assimilation of spillover technology can lead to resilient market value creation.

(iv) While balanced dependency between internal $R \& D$ effort and external market situation can lead to resilient market value creation, it can be turned out to be non-resilient one upon decreasing dependency on OI/R.

(v) Matured products/services as well as R\&D, which have lost attractiveness in the market may result in negative dependency and non-resilient market value creation.

(vi) ICT firms endeavor should focus on accelerating price increase by means of successive efficient new functionality development while minimizing price decrease factors by outsourcing them to other parties.

(vii)Noteworthy accomplishments demonstrated by resilient global ICT firms support this postulate and provide us with constructive suggestions supportive to constructing new business model satisfying both efficiency and resilience in a global competitive market.

These findings provide the following policy suggestions:

(i) R\&D investment strategy should be carefully examined taking special attention of the two-sided nature of ICT with its prices decrease possibility.

(ii) Given the bi-polarization between R\&D matured and R\&D increasing ICT firms, policy facilities should be carefully provided by paying balanced attention to both economies.

(iii) Institutional facilities leveraging the construction of co-evolutionary acclimatization structure in global ICT firms should be provided on priority basis.

(iv) Technopreneurial strategy endeavoring harness the vigor of counter parts in the global ICT market should be encouraged, thus co-evolutional acclimatization should be leveraged.

(v) Platform creating hybrid management of technology fusing indigenous $R \& D$ and assimilated spillover technology should be facilitated.

(vi) Policy systems removing organizational inertia clinging to matured products/services as well as $\mathrm{R} \& \mathrm{D}$ that have lost attractiveness in the market should be accelerated.

Points of future works are summarized as follows

(i) In order to generalize these suggestions, analyses of other high-technology sectors and firms should be conducted.

(ii) A comparative analysis of institutional factors influencing the resilience of

Journal of Technology Management for Growing Economies, Volume 5, Number 1, April 2014 
firms should be conducted.

Institutional

(iii)Further study should be focused on the resilience assessment of innova-

Sources of tion value chain.

Resilience

\section{ENDNOTES}

1. Fig. 1 demonstrated by NRI as a proxy of nation's ICT advancement which consists of Environment (Political and regulatory environment, Business and innovation environment), Readiness (Infrastructure and digital content, Affordability), Usage (Individual usage, Business usage, Government usage), and Impact (Economic impact, Social impact).

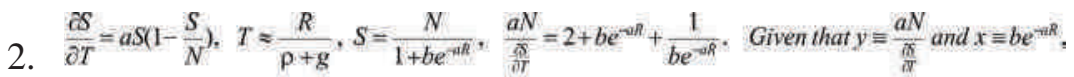
this can be transformed to $y=(1+x)+\left(1+\frac{1}{x}\right)$.

where $\mathrm{S}$ : sales, $\mathrm{N}$ : carrying capacity, $\mathrm{T}$ : technology stock, $\mathrm{R}: \mathrm{R} \& \mathrm{D}$ expenditure, : rate of obsolescence of technology, g: R\&D increasing rate at the initial stage, and a, b: coefficients.

3. As far as the years 2007 and 2010 concerned, while Apple was not R\&D matured firms, given its high R\&D performance in recent years exceeding R\&D matured firms, it is included in this assessment.

4. PMI is an indicator of economic health of manufacturing sector based on five major indicators: new orders, inventory levels, production, supplier deliveries, and the employment environment.

5. Apple demonstrates conspicuously high OI/R as illustrated in Fig. 9.

It dramatically increased this ratio after 2008.

6. Given that the firms seek to profit maximum in the competitive market, marginal productivity of technology corresponds to relative price of technology (ratio of technology price and price of products).

\section{REFERENCES}

Campbell, F. (2008) Elements of Metallurgy and Engineering Alloys, Almere, Netherlands, ASM International.

Chew, M., Watanabe, C. and You, Y. (2010) 'Technology Leapfrogging: Findings from Singapore's Water Industry', Journal of Technology Management for Growing Economies $1: 2$, pp. 29-47.

Cowen, T. (2011) The Great Stagnation, New York, Dutton.

EU (2011) Economics of Industrial Research and Innovation, Brussels, EU.

EU, annual issues. Industrial R\&D Investment Scoreboard. EU, Brussels.

Grimm, V. and Wissel, C. (1997) 'Babel, or the Ecological Stability Discussions: An Inventory and Analysis of Terminology and Guide for Avoiding Confusion', Oecologia, 109:3, pp. 323-334. http://dx.doi.org/10.1007/s004420050090.

Ilmola, L. and Casti, J. (2013) 'Seven Shocks and Finland', Innovation and Supply Chain 
Watanabe, C. Naveed, K. Zhao, W.

Management, 7:3, pp. in print.

IMF (2012) World Economic Outlook Database, Washington, IMF.

Marten, G. (2001) Human Ecology - Basic Concepts for Sustainable Development, London, Earthscan Publishers Ltd.

Neely, Y.A. and Hii, J. (1998) Innovation and Business Performance: A Literature Review, The Judge Institute of Management Studies, University of Cambridge, Cambridge.

Pimentel, D., Westra, L. and Noss, R. (2000) Ecology Integrity - Integrating Environment, Conservation and Health, Washington DC, Island Press.

Ulanowicz, R.E. (1995) 'Ecosystem Integrity: A Casual Necessity' in Westra, L. and Lemons, J. (eds), Perspectives on Ecological Integrity, Dordrecht, Kluwer Academic Publishers, pp. 77-87. http://dx.doi.org/10.1007/978-94-011-0451-7_6

Watanabe, C. Kishioka, M. and Nagamatsu, A. (2003) 'Resilience as a Source of Survival Strategy for High-technology Firms Experiencing Mega-competition’ Technovation, 24:2, pp. 139-152.

Watanabe, C. (2009a) Managing Innovation in Japan: The Role Institutions Play in Helping or Hindering How Companies Develop Technology, Berlin, Springer.

Watanabe, C. (2009b) 'Co-evolutionary Dynamism between Innovation and Institutional Systems: The Rise and Fall of the Japanese System of Management of Technology', in The Science of Institutional Management of Technology: Elucidation of Japan's Indigenous Co-evolutionary Dynamism and Its Accrual to Global Assets, Tokyo, Tokyo Institute of Technology, pp. 21-34.

Watanabe, C., Lei, S. and Ouchi, N. (2009) 'Fusing Indigenous Technology Development and Market Learning for Higher Functionality Development: An Empirical Analysis of the Growth Trajectory of Canon Printers', Technovation 29:2, pp. 265-283. http://dx.doi. org/10.1016/j.technovation.2008.10.008.

Watanabe, C. (2013) 'Innovation-consumption Co-emergence Leads a Resilience Business' Innovation and Supply Chain Management, 7:3, pp. in print. http://dx.doi.org/10.14327/ iscm.7.92.

World Economic Forum (WEF), 2012. The Global Information Technology Report 2012, WEF, Geneva.

Zhao, W., Watanabe, C. and Tou, Y. (2013) 'Co-emergence of Institutional Inoovation Navigates the New Normal in Growing Economies; Journal of Technology Management for Growing Economies, 4:1, pp. 69-81.

Chihiro Watanabe, National University of Singapore and University of Jyvaskyla, Finland. Email: watanabe.c.pqr@gmail.com.

Kashif Naveed, University of Jyvaskyla, Finland.

Email: kashif.naveed80@yahoo.com.

Weilin Zhao, Fujitsu Research Institute, Japan.

Email: weilinzhao.chen@gmail.com. 